Original scientific paper - Izvorni znanstveni rad

UDK: 637.146 .21

\title{
Comparison of chemical, rheological and sensory properties of kefir produced by kefir grains and commercial kefir starter
}

doi: 10.15567/mljekarstvo.2017.0301

\begin{abstract}
Irena Barukčićl ${ }^{*}$, Leo Gracin², Anet Režek Jambrak³, Rajka Božanić ${ }^{1}$
University of Zagreb, Faculty of Food Technology and Biotechnology, Department of Food Engineering, ${ }^{1}$ Laboratory for Technology of Milk and Dairy products, ${ }^{2}$ Laboratory for Technology and Analysis of Wine, ${ }^{3}$ Laboratory for Food Processes Engineering, Pierottijeva 6, 10000 Zagreb, Croatia

Received - Prispjelo: 28.03.2017. Accepted - Prihvaćeno: 25.05.2017.
\end{abstract}

\begin{abstract}
The main objective of this study was to compare chemical, rheological and sensory characteristics of kefir produced by using kefir grains and kefir starter. The intent was also to investigate whether it is plausible to use a combined inoculum (kefir grains and starter) in order to obtain a kefir with improved characteristics in terms of sensory and rheological characteristics. Kefir samples were produced at $25^{\circ} \mathrm{C}$ and $35^{\circ} \mathrm{C}$ by using starter culture XPL-1, kefir grains and their combinations. All of the produced kefir samples were analysed for acidity, total dry matter, ethanol content, syneresis, viscosity and were sensory evaluated by a specially trained panel. There were no significant differences considering the total dry matter, syneresis, ethanol content and acidity. Excess viscosity was observed in samples produced by starter culture at $35^{\circ} \mathrm{C}$, which was described as untypical, yoghurt like and unsatisfactory by a sensory panel. The sample produced at $25^{\circ} \mathrm{C}$ by equal amounts of kefir grains and starter culture received the highest scores at sensory evaluation and showed the best potential for optimizing the further use. Further investigations need to focus on examining kefir properties during the storage period, especially regarding microbiological and sensory properties, ethanol content and texture profile.
\end{abstract}

Key words: kefir, starter culture, kefir grains, viscosity, sensory evaluation

\section{Introduction}

Kefir is fermented milk originating from Caucasus and some other parts of Eastern Europe. Traditionally it was produced by inoculating ewe milk with kefir grains, while nowadays kefir is obtained from cow or goat milk too, and by applying commercially available dairy cultures as well (Wszolek et al., 2006; Tamime et al., 2011). Principally, kefir can be produced by applying one of three types of technologies - the artisanal method, the so called Russian method and the commercial processing. Thereby artisanal production involves milk inoculation by a certain amount of kefir grains and 18-24 h long fermentation at $20-25^{\circ} \mathrm{C}$. The "Russian" method is eligible for production of larger amounts of kefir and relies on fermentation process performed in series, while the commercial method implies milk inoculation with pure cultures isolated from kefir grains (De Oliveira Leite et al., 2013).

In contrast to other fermented milks, kefir is characterised by its specific flavour typical of yeasts and a sparkling mouthfeel originating from constituents like acetic acid, ethanol and $\mathrm{CO}_{2}$. Such properties rely on fermentation processes led by yeasts, lactic acid and acetic acid bacteria and other microorganisms contained in kefir starter culture 
(Arslan, 2014). Several health promoting and therapeutic effects have been attributed to kefir with the most important ones being antimicrobial, antitumor, cholesterol lowering and immune-stimulating impacts. The claimed effects are related to bioactive components, mainly exopolysaccharides and bioactive peptides, present in kefir after the fermentation process (Farnworth, 2005; Ahmed et al., 2013). The composition and properties of kefir and the concentration of bioactive components, as well, depend on milk type but also on the applied culture type (Öner et al., 2010). Kefir grains are a complex symbiotic culture containing a variety of bacteria and yeasts in alterative proportions, which influence the synthesis of specific kefir compounds and make the composition, and the related sensory and therapeutic properties as well, of traditionally produced kefir rather variable. In contrast to that, commercially available kefir starter consists of specific lactic acid bacteria strains and yeasts in well-known and constant proportions which in turn results in kefir drink characterised by a standard composition. Due to absence of some bacteria and/or yeast strains, such kefir drinks may differ considerably in sensory and therapeutic characteristics from the traditionally produced ones. Kefir production by kefir grains in an industrial scale is quite a problem due to the microbiological diversity of grains which greatly depends on their origin, but also on the conditions during handling and storage. So the ratios of specific compounds (i.e. lactic acid, ethanol, carbonyl compounds) defining kefir aroma may differ from one plant to another (Beshkova et al., 2003) leading to the appearance of unstandardized products. In that manner, it would be useful to investigate the possibilities of combining commercially available starter culture, characterised by a constant composition but rarely contain yeasts, and kefir grains, which are variable considering the composition, but claimed to have numerous health effects and contain yeasts responsible for refreshing taste. Some authors have already introduced the idea of secondary fermentation which implies a two stage fermentation conducted in the first part by kefir grains until reaching a certain $\mathrm{pH}$ value (approximately 5.0) at which the grains are removed and a secondary culture is introduced (Sarkar, 2008; Prado et al., 2015). The use of secondary, starter cultures enables the production of kefir with uniform characteristics which can be controlled. The removal of grains is usually performed by sieving which makes the process discontinuous, and might from the technological aspect adversely affect the production technology in terms of preservation of kefir grains, increasing the total production time, controlling the target characteristics, etc. Thus, the aim of this research was to compare chemical, rheological and sensory characteristics of kefir produced by using kefir grains, kefir starter and their combination.

\section{Materials and methods}

For purposes of kefir production ultra-high temperature (UHT) sterilized homogenized milk with $2.8 \%$ milkfat was used. Milk was fermented with kefir grains and with commercially available kefir starter XPL-1 (Christian Hansen, Hershølm, Denmark). Prior to milk fermentation, starting inoculums of both of the selected cultures were prepared. According to Tratnik et al (2006) kefir grain starting inoculum was prepared by adding $1.3 \mathrm{~g}$ of grains into $50 \mathrm{~mL}$ and incubation at $25^{\circ} \mathrm{C}$ for $24 \mathrm{~h}$. The grains were then filtrated and the obtained filtrate was used as a starter. The starting inoculum of commercial kefir starter XPL-1 was prepared according to the producer's instructions. Subsequently, the starting inoculums were combined in following proportions 100:0, 75:25, 50:50, 25:75, 0:100 (XPL-1 : grains), and $5 \%(\mathrm{v} / \mathrm{v})$ of each inoculum prepared that way were applied for milk fermentation in order to produce different kefir samples. Fermentations were performed at $25{ }^{\circ} \mathrm{C}$ and at $35^{\circ} \mathrm{C}$, which was the declared optimal temperature for XPL-1 starter according to producers' information, and were stopped at $\mathrm{pH}$ value of 4.6. Fermentations were repeated three times and all of the produced kefir samples $(n=15)$ were analysed for acidity, the total dry matter content, the ethanol content, syneresis, rheological and sensory properties. The analyses of acidity, syneresis, ethanol content, rheological and sensory properties were performed immediately after kefir production (after reaching $\mathrm{pH}=4.6$ ) while the total dry matter content was determined within 10 days of production. Sample aliquots intended for total dry matter determination were deep freezed immediately after production and stored at $-18{ }^{\circ} \mathrm{C}$ until analyses. 


\section{Analyses of chemical composition}

Active acidity $(\mathrm{pH})$ of kefir was determined by a pH meter Multi 340i (WTW, Wellheim, Germany) and titratable acidity according to the modified method of Soxhlet Henkel (ISO/TS 11869:2012) and expressed as $\%$ of lactic acid. The total dry matter was determined by drying samples at $102 \pm 2{ }^{\circ} \mathrm{C}$ until reaching constant mass (ISO 6731:2010). The content of ethanol was determined by a headspace volatile gas chromatography (GC - Hawlett Packard, Series II 5890, Headspace Sampler, HP 7694) equipped with RTX-624 capillary column $60 \mathrm{~m}$ x $0.32 \mathrm{~mm}$ ID (Restek Corporation, Bellefonte, USA). Hydrogen was a gas carrier with floating rate set to $8 \mathrm{~mL} / \mathrm{min}$, while injecting temperature was adjusted to $210^{\circ} \mathrm{C}$ and detector temperature to $230^{\circ} \mathrm{C}$, respectively.

Evaluation of rheological parameters, syneresis and sensory characteristics

A rotating rheometer Rheometric Scientific RM-180 (Rheometric Scientific, Inc., Piscataway, USA) was used to determine rheological properties of kefir samples tempered at $20^{\circ} \mathrm{C}$. Thereat apparent viscosity $\left(\eta_{\text {app }}\right)$ was calculated at $1.290 \mathrm{~s}^{-1}$ using Newtonian law, in addition to linear least square method for regression analysis as described in detail by Šimunek et al. (2014).

Syneresis of kefir samples was determined by a method described by Riener et al (2010).

Sensory analyses of kefir samples included evaluation of appearance, colour, consistency, odour and taste. It was performed by a group of five specially trained panellists by applying a scoring system of weighted factors on a 20-point scale (ISO/IDF, 2009). Sensations of mouthfeel, creaminess and smoothness were determined within the parameter of taste, similarly as described by Cais-Sokolinska et al. (2016).

\section{Statistical analysis}

Each experiment was repeated three times and the obtained results were expressed as mean \pm SD. Statistical data processing (one-way ANOVA; $\mathrm{p}<0.05$ ) was performed by using Microsoft Office Excel 2010 (Microsoft Corporation, Redmond, WA, USA).

\section{Results and discussion}

One of the objectives of this research was to investigate the influence of temperature and the type of starter on milk fermentation during kefir production. Approximate fermentation time during kefir production is mostly between 16 and $24 \mathrm{~h}$, as Glibowski and Kowalska (2012) concluded. According to data presented in Figure 1, the average fermentation times in the present study were considerably shorter. More precisely, at $25{ }^{\circ} \mathrm{C}$ fermentation process lasted between 10.5 and $12 \mathrm{~h}$, while it was somewhat shorter (approximately $9 \mathrm{~h}$ ) at higher process temperature $\left(35^{\circ} \mathrm{C}\right)$. Regardless of the chosen temperature, fermentation led by commercial culture XPL-1 (sample 100:0) solely was the longest one reaching average time of $12 \mathrm{~h}$. On contrary, fermentations led by kefir grains (sample 0:100) were the shortest ones with approximate time between $9 \mathrm{~h}\left(35^{\circ} \mathrm{C}\right)$ and $10.5 \mathrm{~h}\left(25^{\circ} \mathrm{C}\right)$. Further, it could be noted that the fermentation time of mixed innocula decreased along with the increase of kefir grain share. Such data might indicate that kefir grains could shorten fermentation time if applying them in kefir production led by commercially available kefir cultures.
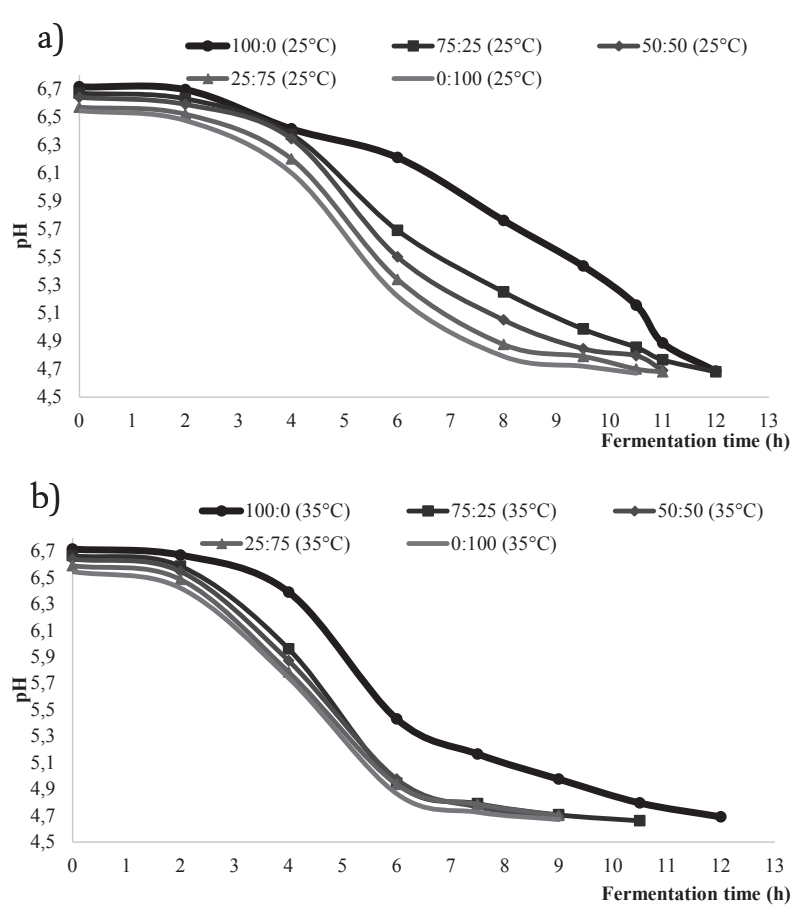

Figure 1. Changes in $\mathrm{pH}$ throughout fermentation (h) at $25^{\circ} \mathrm{C}$ (a) and at $35^{\circ} \mathrm{C}$ (b) led by starter culture XPL-1 (100:0), kefir grains (0:100) and their combination (75:25, $50: 50,25: 75)$ 
Considering acidity of the produced samples, $\mathrm{pH}$ value ranged from 4.58 to 4.65 (Table 1 ) whereby no major differences were observed in relation to fermentation temperature. Magalhaes et al. (2011) reported the $\mathrm{pH}$ value $4.42 \pm 0.01$ for Brazilian kefir produced by fermentation at $25^{\circ} \mathrm{C} \mathrm{pH}$, while Ozdestan and Uren (2010) found $\mathrm{pH}$ of kefir to be between 4.11 and 4.53. Leite et al. (2013) investigated properties of Brazilian kefir produced by kefir grains and reached $\mathrm{pH}$ values around 4.85 after $24 \mathrm{~h}$ of fermentation. Lower $\mathrm{pH}$ was detected during the storage period. Similarly, Irigoyen et al. (2005) reported $\mathrm{pH}$ of kefir being 4.5 after $24 \mathrm{~h}$ of fermentation. Thus, $\mathrm{pH}$ values of the samples produced in the present study did not differ from the ones usually detected in kefir. There is still no clear relationship between the titratable acidity (TA) and $\mathrm{pH}$, although it is known that $\mathrm{pH}$ decreases along with an increase in TA (Waalstra, 2006), which was partially observed in the present study, too (Table 1). The obtained values of TA ranged from $0.686 \pm 0.012 \%$ (sample produced by kefir grains at $35{ }^{\circ} \mathrm{C}$ ) to $0.808 \pm 0.048 \%$ (sample produced by kefir grains at $25{ }^{\circ} \mathrm{C}$ ) (Table 1). Similar results (between 0.64 and $0.76 \%$ ) were obtained by Gul et al. (2015) who examined chemical properties of kefir made from buffalo and cow milk using starter culture and kefir grains. Considering the influence of fermentation temperature, values of TA were significantly different in all samples (Table 1) indicating that the acid production took place in varying intensity whereby higher values were obtained at fermentation temper- ature $25{ }^{\circ} \mathrm{C}$. Such data are probably related to different duration of the fermentation process which lasted between 10.5 and 11 hours at $25{ }^{\circ} \mathrm{C}$ allowing more extensive acid production, while the fermentations conducted at $35{ }^{\circ} \mathrm{C}$ lasted about 9 hours. If looking at TA among different samples, significantly higher values $(\mathrm{p}<0.05$; data not indicated in Table 1$)$ were detected in samples containing starter culture (samples 100:0, 75:25, 50:50, 25:75) than in sample produced by kefir grains, which was especially denoted at fermentation temperature $35{ }^{\circ} \mathrm{C}$. The average total dry matter was between $11.2 \%$ and $11.5 \%$ and was found to be significantly different within samples with prevailing starter culture XPL-1 $(100: 0,75: 25,50: 50)$ if comparing the values obtained at different fermentation temperature (Table 1). Thereat lower contents of the total dry matter could be observed in samples fermented at $25{ }^{\circ} \mathrm{C}$ which corresponds well with higher TA values obviously coming from higher lactose conversion.

Considering ethanol content, average values of approximately $0.040 \mathrm{~g} / 100 \mathrm{~g}$ were detected in almost all samples which corresponded well to previously reported values by Gul et al., 2015 and Ismaiel et al, 2011, respectively. Slightly higher ethanol contents were detected in samples fermented at $35^{\circ} \mathrm{C}$ by innocula consisting only of or mainly of kefir grains (Table 1), which was also found by Gul et al. (2015), Chen et al (2009) and Beskova et al (2002). The highest levels of ethanol were detected in samples produced by kefir grains solely (sample 0:100) and by mixed innocula with kefir

Table 1. Selected physico-chemical parameters of different kefir samples $(n=3)^{*}$

\begin{tabular}{|c|c|c|c|c|c|c|c|c|c|c|}
\hline \multirow{2}{*}{ Sample } & \multicolumn{2}{|c|}{$100: 0^{* *}$} & \multicolumn{2}{|c|}{$75: 25$} & \multicolumn{2}{|c|}{$50: 50$} & \multicolumn{2}{|c|}{$25: 75$} & \multicolumn{2}{|c|}{$0: 100$} \\
\hline & $25^{\circ} \mathrm{C}$ & $35^{\circ} \mathrm{C}$ & $25^{\circ} \mathrm{C}$ & $35^{\circ} \mathrm{C}$ & $25^{\circ} \mathrm{C}$ & $35^{\circ} \mathrm{C}$ & $25^{\circ} \mathrm{C}$ & $35^{\circ} \mathrm{C}$ & $25^{\circ} \mathrm{C}$ & $35^{\circ} \mathrm{C}$ \\
\hline $\mathrm{pH}$ & $\begin{array}{c}4.59 \\
\pm 0.01 \\
\end{array}$ & $\begin{array}{c}4.62 \\
\pm 0.01 \\
\end{array}$ & $\begin{array}{c}4.65 \\
\pm 0.02 \\
\end{array}$ & $\begin{array}{c}4.58 \\
\pm 0.03 \\
\end{array}$ & $\begin{array}{c}4.65 \\
\pm 0.03 \\
\end{array}$ & $\begin{array}{c}4.58 \\
\pm 0.02 \\
\end{array}$ & $\begin{array}{c}4.63 \\
\pm 0.04 \\
\end{array}$ & $\begin{array}{c}4.59 \\
\pm 0.02 \\
\end{array}$ & $\begin{array}{c}4.65 \\
\pm 0.03 \\
\end{array}$ & $\begin{array}{c}4.58 \\
\pm 0.02 \\
\end{array}$ \\
\hline TA (\%) & $\begin{array}{c}0.803 \\
\pm 0.048^{\mathrm{a}}\end{array}$ & $\begin{array}{c}0.738 \\
\pm 0.086^{\mathrm{b}}\end{array}$ & $\begin{array}{c}0.788 \\
\pm 0.022^{\mathrm{a}}\end{array}$ & $\begin{array}{c}0.725 \\
\pm 0.015^{\mathrm{b}}\end{array}$ & $\begin{array}{c}0.788 \\
\pm 0.044^{\mathrm{a}} \\
\end{array}$ & $\begin{array}{c}0.718 \\
\pm 0.042^{\mathrm{b}} \\
\end{array}$ & $\begin{array}{c}0.772 \\
\pm 0.078^{\mathrm{a}}\end{array}$ & $\begin{array}{c}0.686 \\
\pm 0.024^{\mathrm{b}}\end{array}$ & $\begin{array}{c}0.727 \\
\pm 0.032^{\mathrm{a}}\end{array}$ & $\begin{array}{c}0.686 \\
\pm 0.012^{\mathrm{b}}\end{array}$ \\
\hline $\begin{array}{l}\text { Syneresis } \\
(\mathrm{mL})\end{array}$ & $\begin{array}{c}14 \\
\pm 0.02\end{array}$ & $\begin{array}{c}14 \\
\pm 0.70\end{array}$ & $\begin{array}{c}14.1 \\
\pm 0.82\end{array}$ & $\begin{array}{c}14.3 \\
\pm 0.41\end{array}$ & $\begin{array}{c}14.7 \\
\pm 0.23\end{array}$ & $\begin{array}{c}15 \\
\pm 0.70\end{array}$ & $\begin{array}{c}15.6 \\
\pm 0.41\end{array}$ & $\begin{array}{c}15.3 \\
\pm 0.81\end{array}$ & $\begin{array}{c}15.7 \\
\pm 0.40\end{array}$ & $\begin{array}{c}15.7 \\
\pm 0.40\end{array}$ \\
\hline $\begin{array}{c}\text { Dry } \\
\text { matter } \\
(\%)\end{array}$ & $\begin{array}{c}10.8 \\
\pm 0.40^{\mathrm{a}}\end{array}$ & $\begin{array}{c}11.5 \\
\pm 0.53^{\mathrm{b}} \\
\end{array}$ & $\begin{array}{c}11.2 \\
\pm 0.33^{\mathrm{a}} \\
\end{array}$ & $\begin{array}{c}11.7 \\
\pm 0.18^{\mathrm{b}} \\
\end{array}$ & $\begin{array}{c}11.3 \\
\pm 0.29^{\mathrm{a}}\end{array}$ & $\begin{array}{c}11.8 \\
\pm 0.32^{\mathrm{b}} \\
\end{array}$ & $\begin{array}{c}11.0 \\
\pm 0.29\end{array}$ & $\begin{array}{c}11.0 \\
\pm 0.46\end{array}$ & $\begin{array}{c}11.3 \\
\pm 0.19\end{array}$ & $\begin{array}{c}11.4 \\
\pm 0.15\end{array}$ \\
\hline $\begin{array}{c}\text { Ethanol } \\
(\mathrm{g} / 100 \mathrm{~g})\end{array}$ & $\begin{array}{l}0.040 \\
\pm 0.02\end{array}$ & $\begin{array}{c}0.041 \\
\pm 0.003\end{array}$ & $\begin{array}{l}0.041 \\
\pm 0.01\end{array}$ & $\begin{array}{l}0.041 \\
\pm 0.01\end{array}$ & $\begin{array}{c}0.042 \\
\pm 0.005^{\mathrm{a}}\end{array}$ & $\begin{array}{c}0.047 \\
\pm 0.01^{\mathrm{b}}\end{array}$ & $\begin{array}{c}0.048 \\
\pm 0.005^{\mathrm{a}}\end{array}$ & $\begin{array}{c}0.059 \\
\pm 0.08^{\mathrm{b}}\end{array}$ & $\begin{array}{c}0.049 \\
\pm 0.005^{\mathrm{a}}\end{array}$ & $\begin{array}{c}0.064 \\
\pm 0.08^{\mathrm{b}}\end{array}$ \\
\hline
\end{tabular}

*the presented values are a men of 3 replicates \pm standard deviation

${ }^{* *}$ sample $x: y=\mathrm{x}$ - the amount (\%) of starter culture XPL-1 in the inoculum; $\mathrm{y}$ - the amount (\%) of kefir grains in the inoculum

$\mathrm{a}, \mathrm{b}$ Values assigned with different letters within the same sample/treatment were significantly different at $\mathrm{p}<0.05$ 
grain prevalence (sample 25:75) (Table 1). If looking at the values obtained within one type of inoculum, significantly higher values were detected in samples produced at $35{ }^{\circ} \mathrm{C}$, which was especially denoted in sample 0:100 containing only kefir grains. Since ethanol is produced by yeasts which were present in kefir grains, they could have inhibited metabolic activities of lactic acid and/or acetic acid producing strains, as Collar (1996) previously indicated. Accordingly, TA was lower in samples produced by innocula containing solely and/or higher amounts of kefir grains (Table 1).

The texture of fermented milks including kefir is of great importance and needs to remain more or less unchanged during the storage time, as Robinson and Tamime concluded (1993). Texture stability is directly related to the water binding and/or holding capacity by the casein matrix in the coagulated milk. Thus, one of methods for examining texture stability is by determining syneresis. Excess syneresis is considered as undesired in terms of nutritive and sensory quality of fermented milks. Average values obtained by analysing kefir samples produced within the present study were approximately $15 \mathrm{~mL} / 30 \mathrm{~g}$ during 5 hours (Table 1). Slightly lower values were noticed for samples fermented by innocula containing starter culture in prevalence or solely. Similar findings were observed by Montanuci et al. (2012) who also compared characteristics of kefir produced by kefir grains and kefir starter culture, with or without addition of inulin. Montanuci et al. (2012) also observed lower syneresis for kefir fermented by starter culture and/or with added inulin. Such observations might be explained by higher ability of starter culture to produce extracellular polysaccharides which are known for their viscosity and texture improving ability (Farnworth, 2005). Additionally, if we consider results relating to rheological analysis of the produced kefir samples, the above mentioned explanations appear more probable. As presented in Figure 2, kefir samples fermented by starter culture XPL-1 solely (sample 100:0) or in prevalence considering innocula composition (sample 75:25) showed higher viscosity values, especially when fermentation was carried out at $35^{\circ} \mathrm{C}$ (Figure 2b) when the viscosity in general was up to 5 times higher than at $25^{\circ} \mathrm{C}$ (Figure 2a). According to producer's specification (Anonymus 1), starter culture XPL-1 contains meshopillic (Lactococcus sp.) and thermophillic (Streptococcus thermophilus) strains of lactic acid bacteria which are responsible for extraordinary texture with an optimum working temperature at $35^{\circ} \mathrm{C}$. Those are most probably reasons for extremely higher viscosity observed in kefir samples produced at $35^{\circ} \mathrm{C}$ and fermented by innocula containing only or mainly XPL-1 culture (samples 100:0, 75:25). However, during sensory evaluation those samples were mainly described as untypical and graded with lower scores whereby the extraordinary high viscosity was listed as one of the most important reason.

As presented in Figure 3, panel consisting of 5 specially trained evaluators rated higher kefir samples produced at $25{ }^{\circ} \mathrm{C}$ (Figure 3a). Regardless of the fermentation temperature, it could also be noticed that the higher was the content of kefir grains in the used innocula, the better sensory score was obtained. Previously mentioned excess viscosity of samples produced at $35{ }^{\circ} \mathrm{C}$ and containing mostly or only starter culture was reflected in lower scores received for texture evaluation (Figure $3 b$ ), but also for taste (Figure 3c). According to the impressions of the panellists, samples produced at $25^{\circ} \mathrm{C}$ were in general recognized as kefir, while samples produced
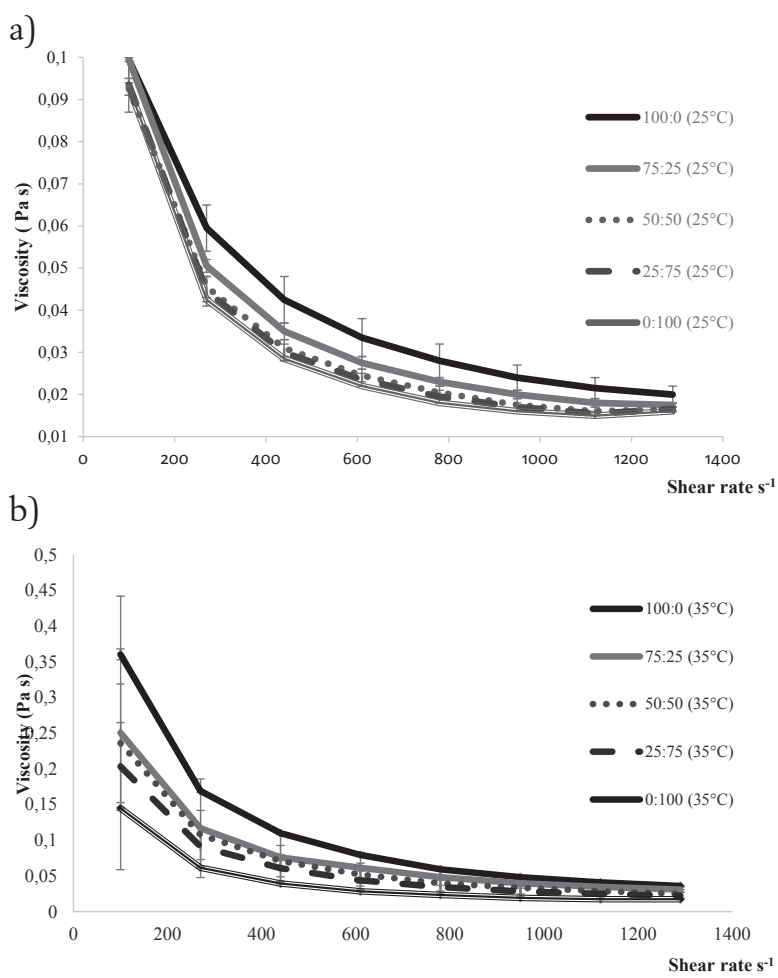

Figure 2. Viscosity (Pa s) of kefir samples produced at $25^{\circ} \mathrm{C}$ (a) and at $35^{\circ} \mathrm{C}$ (b) led by starter culture XPL-1 (100:0), kefir grains (0:100) and their combination $(75: 25,50: 50,25: 75)$ 
at $35{ }^{\circ} \mathrm{C}$ by XPL-1 culture solely or in prevalence were more yoghurt like why they received lower scores (Figure 3). The highest score was obtained for kefir produced at $25{ }^{\circ} \mathrm{C}$ (Figure 3a) by inoculum containing equal quantities of kefir grains and starter culture XPL-1 (sample 50:50). According to the comments of panellists, this sample had the best combination of viscosity and freshness with a scent of prickling mouthfeel which was recognized as typical kefir drink.

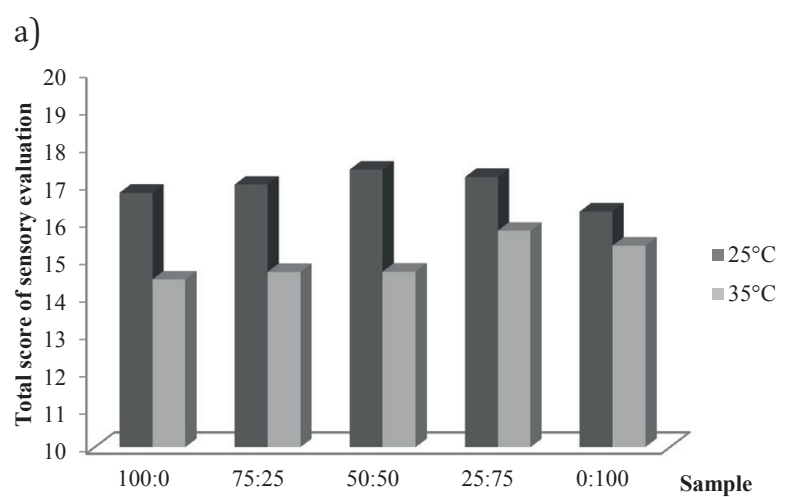

b)

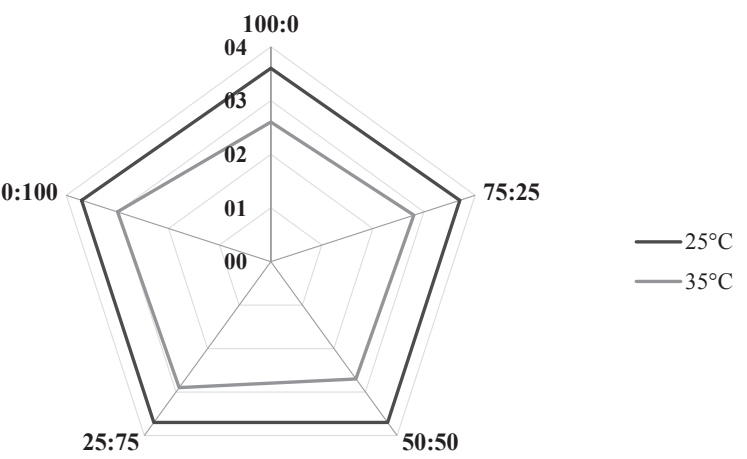

c)

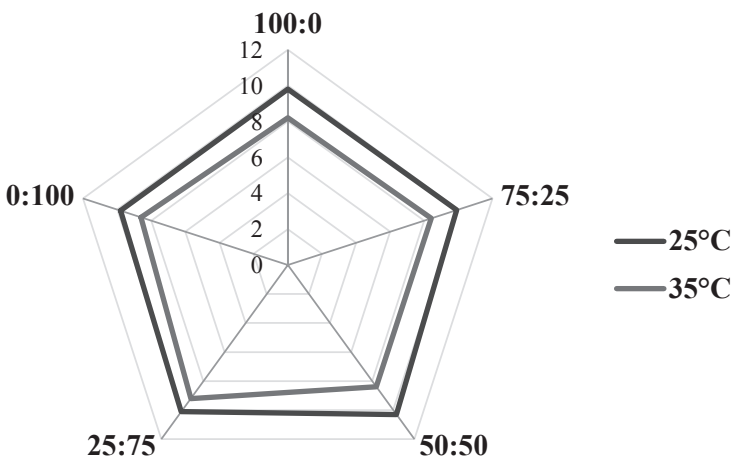

Figure 3. Total scores (a), scores for texture (b) and for taste (c) recieved at sensory evaluation of kefir samples produced at $25{ }^{\circ} \mathrm{C}$ and at $35^{\circ} \mathrm{C}$ led by starter culture XPL-1 (100:0), kefir grains $(0: 100)$ and their combination $(75: 25,50: 50,25: 75)$

\section{Conclusion}

The aim of this study was to compare physical, chemical and sensory properties of kefir produced by commercial starter culture, by kefir grains and by their combination. Considering all of the obtained results, the shortest fermentation times (approximately $9 \mathrm{~h}$ ) were observed at $35^{\circ} \mathrm{C}$ for samples produced by kefir grains solely or in prevalence. On contrary, samples produced by starter culture were characterised by the longest fermentation time (between 11 and $12 \mathrm{~h}$ ), regardless of the fermentation temperature. There were no considerable differences in acidity, the total dry matter and syneresis among the produced samples, regardless of the inoculum type or the fermentation temperature. Higher amounts of ethanol were determined in samples fermented at $35^{\circ} \mathrm{C}$ by kefir grains solely or in prevalence which most probably originated from yeast activity. Excess viscosity was detected in samples fermented only/or in prevalence by starter culture, which was recognized as untypical by the sensory panel. Regarding sensory evaluation the highest scores were obtained for kefir sample fermented at $25{ }^{\circ} \mathrm{C}$ by equal amounts of kefir gains and starter culture. That combination showed to have the most potential for further investigations which need to focus on examining kefir properties during the storage period, especially regarding microbiological and sensory properties, ethanol content and texture profile.

\section{Usporedba kemijskog sastava, reoloških $i$ senzorskih svojstava kefira proizvedenog primjenom kefirnih zrnaca $i$ starter kulture}

\section{Sažetak}

Cilj ovog rada bio je usporediti kemijski sastav, reološka i senzorska svojstva kefira proizvedenog pomoću kefirnih zrnaca i starter kulture. Osim toga, namjera je bila ispitati i opravdanost uporabe inokuluma dobivenog kombinacijom kefirnih zrnaca i starter kulture u svrhu postizanja kefira poboljšanih senzorskih i reoloških svojstava. Uzorci kefira proizvedeni su pri $25^{\circ} \mathrm{C}$ i $35^{\circ} \mathrm{C}$ primjenom starter kulture XPL-1, kefirnih zrnaca i njihove međusobne kombinacije. Svim proizvedenim uzorcima određivana 
je kiselost, ukupna suha tvar, udio etanola, sinereza, viskoznost i senzorska svojstva. Pri tom nisu zamijećene značajnije razlike u ukupnoj suhoj tvari, sinerezi, udjelu etanola i kiselosti. Međutim, u uzorcima proizvedenim pri temperaturi fermentacije $35{ }^{\circ} \mathrm{C}$ utvrđena je prekomjerna viskoznost koju je senzorski panel okarakterizirao kao netipičnu, svojstvenu jogurtu i nezadovoljavajuću. Uzorak proizveden fermentacijom pri temperaturi od $25^{\circ} \mathrm{C}$ primjenom inokuluma sastavljenog od podjednakih dijelova starter kulture i kefirnih zrnaca najbolje je ocijenjen od strane senzorskog panela te je pokazao najveći potencijal za optimiranje i daljnju uporabu. Buduća istraživanja trebala bi se usredotočiti na ispitivanje svojstava kefira tijekom skladištenja, prije svega $\mathrm{u}$ pogledu mikrobioloških i senzorskih svojstava, udjela etanola i teksture.

\section{Ključne riječi: kefir, starter kultura, kefirna zrnca, viskoznost, senzorska ocjena}

\section{References}

1. Ahmed, Z., Wang, Y., Ahmad, A., Khan, S.T., Nisa, M., Ahmad, H., Afreen, A. (2013): Kefir and health: A contemporary perspective. Critical Reviews in Food Science and Nutrition 53, 422-434. https://doi.org/10.1080/10408398.2010.540360

2. Anonymus 1: http://www.hjemmeriet.dk/ChrHansen/ Products/XPL-1/PI_EU_XPL-1_675876_EN.pdf, last assessed 20.10.2016

3. Arslan, S. (2014): A review: chemical, microbiological and nutritional characteristics of kefir. CyTA - Journal of Food, 1-6.

4. Beshkova, D.M., Simova, E.D., Simov, Z.I., Frengova, G.I. Spasov, Z.N. (2002): Pure cultures for making kefir. Food Microbiology 19, 537-544. https://doi.org/10.1006/fmic.2002.0499

5. Cais-Sokolińska, D., Jacek Wójtowski, J., Pikul, J. (2016): Rheological, texture and sensory properties of kefir from mare's milk and its mixtures with goat and sheep milk. Mljekarstvo 66 (4), 272-281. https://doi.org/10.15567/mljekarstvo.2016.0403

6. Chen, T.H., Wang, S.Y, Chen, K.N., Liu, J.-R., Chen, M.J. (2009): Microbiological and chemical properties of kefir manufactured by entrapped microorganisms isolated from kefir grains. Journal of Dairy Science 92, 3002-3013. https://doi.org/10.3168/jds.2008-1669
7. Collar, C. (1996): Review: Biochemical and technological assessment of the metabolism of pure and mixed cultures of yeast and lactic acid bacteria in breadmaking applications. Food Science and Technology International 2, 349-367. https://doi.org/10.1177/108201329600200601

8. De Oliveira Leite, A.M., Miguel, M.A.C., Peixoto, R.S., Rosado, A.S., Silva, J.T., Paschoalin flosi, V.M. (2013): Microbiological, technological and therapeutic properties of kefir: a natural probiotic beverage. Brazilian Journal of Microbiology 44 (2), 341-349. https://doi.org/10.1590/S1517-83822013000200001

9. Farnworth, E.R. (2005): Kefir a complex probiotic. Food Science and Technology 2, 1-17. https://doi.org/10.1616/1476-2137.13938

10. Glibowski, P., Kowalska, A. (2012): Rheological, texture and sensory properties of kefir with high performance and native inulin. Journal of Food Engineering 111 (2), 299-304. https://doi.org/10.1016/j.jfoodeng.2012.02.019

11. Gul, O., Mortas,M., Atalar, I., Dervisoglu, M., Kahyaoglu, T. (2015): Manufacture and characterization of kefir made from cow and buffalo milk, using kefir grain and starter culture. Journal of Dairy Science 98, 1517-1525. https://doi.org/10.3168/jds.2014-8755

12. Irigoyen, A., Arana, I., Castiella, M., Torre, P., Ibanez, F.C. (2005): Microbiological, physicochemical, and sensory characteristics of kefir during storage. Food Chemistry 90, 613-620. https://doi.org/10.1016/j.foodchem.2004.04.021

13. Ismaiel, A., Ghaly, M., El-Naggar, A. (2011): Some physicochemical analyses of kefir production under different fermentation conditions. Journal of Science and Industrial Research, India 70, 365-372.

14. ISO 6731:2010 Milk, Cream and Evaporated Milk. Determination of total solids content - reference method.

15. ISO 22935-3:2009 (IDF 99-3:2009) Milk and milk products - Sensory analysis - Part 3: Guidance on a method for evaluation of compliance with product specifications for sensory properties by scoring.

16. ISO/TS 11869:2012 (IDF/RM 150:2012) Fermented milks - Determination of titratable acidity.

17. Leite, A.M.O., Leite, D.C.A., Del Aguila, E.M., Alvares, T.S., Peixoto, R.S., Miguel, M.A.L., Silva, J.T., Paschoalin, V.M.F. (2013): Microbiological and chemical characteristics of Brazilian kefir during fermentation and storage processes. Journal of Dairy Science 96, 4149-4159. https://doi.org/10.3168/jds.2012-6263

18. Magalhaes, K.T., Dragone, G., Melo Pereira, G.V., Oliveira, J. M., Domingues, L., Teixeira, J.A., Silva, J.B.A., Schwan, R.F. (2011): Comparative study of the biochemical changes and volatile compound formations during the production of novel whey-based kefir beverages and traditional milk kefir. Food Chemistry 126 (1), 249-253. https://doi.org/10.1016/j.foodchem.2010.11.012 
19. Montanuci, F.D., Pimentel, T.C., Garcia, S., Prudencio, S.H. (2012): Effect of starter culture and inulin addition on microbial viability, texture, and chemical characteristics of whole or skim milk Kefir. Ciência Tecnologica Alimentaria Campinas 32 (4), 850-861. https://doi.org/10.1590/s0101-20612012005000119

20. Ozdestan, O., Uren, A. (2010): Biogenic amine content of kefir: a fermented dairy product. European Food Research Technology 231(1), 101-107. https://doi.org/10.1007/s00217-010-1258-y

21. Öner, Z., Karahan, A.G., Çakmakçı, M.L. (2010): Effects of different milk types and starter cultures on kefir. Gida 35 (3), 177-182.

22. Prado, M.R., Blandón, L.M., Vandenberghe, L.P.S., Rodrigues, C., Castro, G.R., Thomaz-Soccol, V., Soccol, C.R. (2015): Milk kefir: composition, microbial cultures, biological activities, and related products. Frontiers in Microbiology 6, 1-10. https://doi.org/10.3389/fmicb.2015.01177

23. Riener, J., Noci, F., Cronin, D.A, Morgan D.J., Lyng, J.G. (2010): A comparison of selected quality characteristics of yoghurts prepared from thermosonicated and conventionally heated milks. Food Chemistry 119, 1108-1113. https://doi.org/10.1016/j.foodchem.2009.08.025

24. Robinson, R.K., Tamime, A.Y. (1993): Manufacture of yoghurt and other fermented milks. In: Modern Dairy Technology Advances in Milk Products, 2. Ed (Robinson, R. K.), Elsevier Applied Science Publishers, London, 1-26. https://doi.org/10.1007/978-1-4684-8172-3_1
25. Sarkar, S. (2008): Biotechnological innovations in kefir production: a review. British Food Journal, 110 (3), 283-295. https://doi.org/10.1108/00070700810858691

26. Šimunek, M., Režek Jambrak, A., Dobrović, S., Herceg, Z., Vukušić, T. (2014): Rheological properties of ultrasound treated apple, cranberry and blueberry juice and nectar. Journal Food Science and Technology 51 (12), 3577-3593. https://doi.org/10.1007/s13197-013-0958-2

27. Tamime, A.Y., Wszolek, M., Božanić, R., Özer, B. (2011): Popular ovine and caprine fermented milks. Small Ruminant Research 101, 2-16. https://doi.org/10.1016/j.smallrumres.2011.09.021

28. Tratnik, Lj., Božanić, R., Drgalić, I., Herceg, Z. (2006): The quality of plain and supplemented kefir from goat's and cow's milk. International Journal of Dairy Technology 59 (1), 40-46. https://doi.org/10.1111/j.1471-0307.2006.00236.x

29. Walstra, P., Wouters, J.T.M., Geurts, T.J. (2006): Milk properties dairy science and technology ( $2^{\text {nd }}$ ed.). Boca Raton, FL, USA: CRC Press

30. Wszolek, M., Kupiec-Teahan, B., Skov Guldager, H., Tamime, A.Y. (2006): Production of kefir, koumiss and other related products. In: Fermented Milks (Tamime, A.Y., ured.) Blackwell Publishing, Oxford, UK, 174-216. https://doi.org/10.1002/9780470995501.ch8 